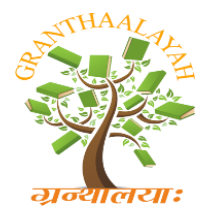

INTERNATIONAL JOURNAL OF RESEARCH -

GRANTHAALAYAH

A knowledge Repository

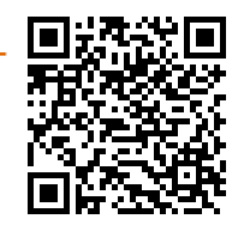

Science

\title{
EFFECT OF CELLULASE ENZYMES AND SWELLING AGENTS ON COLOUR STRENGTH (K/S) AND COLOURFASTNESS PROPERTY OF HANDLOOM COTTON FABRIC DYED WITH BUTEA FRONDOSA DYE
}

\author{
Sunita Dixit *1 \\ *1 Assistant Professor, Department of Home Science, Vasant Kanya Mahavidyalaya (Banaras \\ Hindu University), Kamachha, Varanasi, INDIA
}

\begin{abstract}
Cellulase and swelling agents are known to be effective in improving the colour strength of cotton. Nowadays, the handloom fabrics are much preferred due to development of innovative designs and their comfort in wearing Due to increased environmental awareness the use of natural dyes are much preferred in dyeing of handloom fabrics. But, khadi cotton has some major shortcomings like less dyeability. Keeping in view that the pretreatment of khadi cotton with cellulases, swelling agents and combination of cellulases and swelling agents before dyeing improves the colour strength properties, the present study was planned. The khadi cotton samples were treated with optimized conditions of enzymes and swelling agents. The optimum pH, concentration, treatment time and temperature selected for the acid cellulase enzyme treatment were $5.5,1.5 \%$ (owf), 45 minutes and $50^{\circ} \mathrm{C}$, respectively whereas in case of neutral cellulase enzyme, it was $7.5,2.0 \%$ (owf), 70 minutes and $70^{\circ} \mathrm{C}$ respectively. The optimum concentration, treatment time and temperature selected for sodium hydroxide treatment were $20 \% \mathrm{w} / \mathrm{v}, 60$ minutes and $60^{\circ} \mathrm{C}$, respectively. In case of ethylenediamine, $80 \% \mathrm{w} / \mathrm{v}, 60$ minutes and $70^{\circ} \mathrm{C}$ were selected as optimum concentration, treatment time and temperature, respectively. In case of zinc chloride treatment, the optimum concentration, treatment time and temperature were selected as $80 \% \mathrm{w} / \mathrm{v}, 60$ minutes and $70^{\circ} \mathrm{C} .5 \mathrm{~g}$ Butea frondosa dye extracted for 75 minutes gave best results on khadi cotton when dyeing was carried out for 90 minutes It was observed that out of various concentrations of mordants used with Butea frondosa dye, best shades of colour were obtained by using $0.04 \mathrm{~g}$ of Alum, $0.01 \mathrm{~g}$ of Copper sulphate, $5 \mathrm{~g}$ each of Babool bark.On optimizing the method of mordanting, best results were obtained with Butea frondosa dye when samples were simultaneous mordanted and dyed with Alum, Babool bark and Alum. Pre-mordanting was selected for Copper sulphate. . It was found that for all the enzyme treated (acid and neutral cellulase) as well as swelling agents treated (Sodium hydroxide, Ethylenediamine and Zinc chloride) samples, the colour strength and colourfastness was increased in comparison to the untreated samples.
\end{abstract}

Keywords:

Cotton, colour strength, enzymes, swelling agents, Butea frondosa dye. 
Cite This Article: Sunita Dixit, "EFFECT OF CELLULASE ENZYMES AND SWELLING AGENTS ON COLOUR STRENGTH (K/S) AND COLOURFASTNESS PROPERTY OF HANDLOOM COTTON FABRIC DYED WITH BUTEA FRONDOSA DYE" International Journal of Research - Granthaalayah, Vol. 3, No. 10(2015): 65-74.

\section{INTRODUCTION}

Cotton is produced in over 50 countries worldwide, averaging 20-24 million tons per year. India is one of the largest consumers of cotton, accounting for about $60 \%$ of the total consumption of cotton (Furter et al., 2007). Cotton, whether present as fibre, yarn or fabric, requires some form of pre treatment to make it suitable for dyeing and finishing. The basic function of pre treatment is to impart uniform and good absorbency and whiteness without chemically damaging cotton. The natural impurities in cotton are pectin, protein, wax and minerals, whereas added impurities could be lubricating oils, sizes etc. In recent years efforts are being made to develop a mild and environment friendly process. Thus, enzymatic pre treatment has assumed more importance due to present concern of clean and eco-friendly environment. The preparation processes of cotton textiles include singeing, desizing, scouring, bleaching and mercerization. These treatments remove natural and human induced impurities, i.e., non-cellulosic constituents and other unwanted substances and increase the affinity of cellulose for dyes and finishes. In addition, colour enhancement can be accomplished through the treatment of cotton with cellulase enzymes either before or after dyeing. The increased enhancement occurs because of the removal of fibers, which give the surface of cotton fabric a frosted appearance (Lewin, 2007). Tsatsaroni et al. (1998) conducted experiment for dyeing cotton and wool fibres after enzymatic treatment with the crude water extract of saffron stigmas (Crocus sativus L.) as well as crocin, the yellow pigment isolated from Crocus sativus L. were used. The dyeing results were compared with those obtained with another yellow natural pigment, curcumin. Wash and light fastness of all dyed samples were studied. Thakare (2006) studied the treatment of hydroxylamine sulphate at various concentrations and temperatures on moisture regain and dye uptake on cotton fibre. Moisture regain from $8.15 \%$ for cotton was raised to $13.98 \%$ when the treatment was carried out by $60 \%(\mathrm{w} / \mathrm{v})$ concentration of hydroxylamine sulphate solution at $32^{\circ} \mathrm{C}$. The dyeing results showed that the Reactive dye content (Amectic Red EB Ex H/C) from $2.27 \mathrm{~g} / \mathrm{kg}$ of fibre for control increased to $2.87 \mathrm{~g} / \mathrm{kg}$ fibre, when the treatment was carried out by $60 \% \mathrm{w} / \mathrm{v}$ concentration of hydroxylamine at room temperature. This showed an increase in dye content by $26.43 \%$. Hydroxylamine sulphate gave positive results at higher temperatures, but lower concentrations. Constanta et al. (2006) examined the influence of some swelling agents with reduced water content on final properties of cotton fabrics. There were selected properties generally used to characterize mercerized cotton that are technologically important, such as water retention, shrinkage, stiffness, crease recovery angle and hand. Correlations have been established between structural changes induced by the swelling agents and final properties of cotton fabric. Nair (2006) studied the changes in fine structure of native cotton cellulose as a result of three typical swelling treatment viz., with Sodium hydroxide $(\mathrm{NaOH})$, Ethylenediamine (EDA) and Zinc chloride $\left(\mathrm{ZnCl}_{2}\right)$. The de-crystallizing action of the three swelling agents were in the order: $\mathrm{NaOH}>\mathrm{EDA}>\mathrm{ZnCl}_{2}>$ Native cotton on treatment with swelling agents, showed decrease in absolute crystallinity or lateral order and a decrease in both crystallite length and width. 


\section{MATERIALS AND METHODS}

\subsection{SPECIFICATION OF TEST SAMPLE}

Pure white handloom cotton fabric was procured from "Gandhi Ashram" of local market in Pantnagar (Uttarakhand). The fabric specifications i.e. the fabric count, weight per unit area and thickness of the chosen material for the study was calculated.

Specifications of the handloom cotton fabric used in the present study

\begin{tabular}{|l|l|l|}
\hline $\begin{array}{l}\text { Fabric count } \\
(\text { warp/filling })\end{array}$ & $\begin{array}{l}\text { Weight per unit area } \\
\left(\mathrm{g} / \mathrm{m}^{2}\right)\end{array}$ & $\begin{array}{l}\text { Fabric thickness } \\
(\mathrm{mm})\end{array}$ \\
\hline $27 / 18$ & 157 & 0.55 \\
\hline
\end{tabular}

\subsection{COLOUR MEASUREMENT OF DYED SAMPLES}

The principle involved in colour measurement is to project specific light on a sample and measure the reflectance of light from it. The colour instrument consists of two parts; first optical sensor and second signal processor. The optical sensor measures the reflectance of sample at different wavelength. The optical sensor may be a spectrophotometer. The reflected light is converted to photocurrent and is passed to signal processor acquisition of colour parameters. The Kubelka Munk theory makes it possible to predict the colour recipe.

$(\mathrm{K} / \mathrm{S}) \lambda=(1-\mathrm{R}) \lambda^{2}$

$$
2 \mathrm{R} \lambda
$$

in which $\mathrm{R}$ is the reflected light at wavelength $\lambda$,

$\mathrm{K}$ is the coefficient of scattering at $\lambda$,

$\mathrm{S}$ is the coefficient of absorption of the dye at $\lambda$.

The K/S values were determined using Gretag Macbeth Color Eye 7000A. The samples were folded twice and placed at the eye of the instrument and light was passed. The reflectance was displayed on the computer screen. Each sample was oriented twice by reversing the direction of the specimen to the light. The K/S values were noted down directly from the computer screen (Mehta and Bhardwaj, 1998).

Experiments were conducted to determine optimum values of four variables for acid and neutral cellulase enzyme treatment, namely, $\mathrm{pH}$, concentration, treatment time and temperature. Concentration, treatment time and temperature were the three variables optimized for the swelling agents. Dyeing variables i.e. concentration of dye material, extraction time, dyeing time, mordant concentration and method of mordanting with natural and metallic mordants were optimized.

\subsection{EVALUATION OF COLOURFASTNESS PROPERTIES}

The colourfastness test was done against following;

Light fastness test (IS: 686-1957)

Washing fastness test (IS: 3361-1979)

Perspiration fastness (IS: 971-1956)

Fastness to rubbing AATCC-08 


\subsection{WEIGHTED MEAN SCORE}

Weighted mean score was calculated for quantifying the ratings of colourfastness. The fastness to washing was given highest weight 4 since it is most important followed by fastness to light, rubbing and perspiration which were given weight 3,2 and 1, respectively.

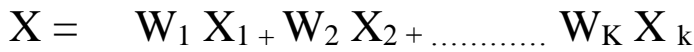

$\mathrm{W}_{1}+\mathrm{W}_{2}+\ldots . .+\mathrm{W}_{\mathrm{K}}$

\section{RESULT AND DISCUSSION}

\subsection{DYEING OF SAMPLES TREATED WITH ENZYMES AND SWELLING AGENTS}

The handloom cotton samples were treated with optimized conditions of enzymes and swelling agents. The dyeing of untreated as well as treated samples was carried out with Butea frondosa dye. On the basis of colour strength $(\mathrm{K} / \mathrm{S})$, the comparisons were made between the treated and untreated dyed cotton samples.

\subsection{COLOUR STRENGTH (K/S) OF TREATED HANDLOOM COTTON DYED WITH BUTEA FRONDOSA DYE}

The colour strength (K/S) of cellulase enzymes and swelling agents treated and untreated handloom cotton samples dyed with Butea frondosa dye using natural and metallic mordants is given in table 1. It is clear from the table 1 that in case of Butea frondosa dye in comparison of untreated dyed sample, natural as well as metallic mordants showed enhancement in K/S values. Metallic mordants showed higher depth in dyeing as compared to natural mordants. Table 1 depicted that among metallic mordants higher depth in dyeing with Copper sulphate (4.823) was observed as compared to Alum (4.268). When K/S values of natural mordants were compared, it was found that Myrobolan (4.124) exhibited higher depth in dyeing than Babool bark (3.986).

The K/S values of cellulase treated samples dyed with Butea frondosa dye were enhanced in comparison with untreated samples as shown in table 1. According to Buschle-Diller et al. (1998) cellulases not only change the fibre surface, but also reduce the amount of existing amorphous areas as well as creating new dyeable regions. It was found that the sample treated with neutral cellulase enzyme exhibited higher depth of dyeing than acid cellulase treated samples. The K/S values of acid cellulase enzyme treated samples, without mordant, mordanted with Babool bark, Myrobolan, Alum and Copper sulphate were 2.948, 4.994, 5.326, 5.549 and 6.648, respectively, while in case of neutral cellulase enzyme treated samples the K/S values, without mordant, Babool bark, Myrobolan, Alum and Copper sulphate were 3.137, 5.418, 5.530, 5.991 and 6.875, respectively. The enhancement in the extent of biofinishing could be interpreted in terms of higher enzymatic activity along with greater wettability and swellability of cellulose structure, (i) increasing extent of enzymatic hydrolysis, biopolishing and fabric surface modification (ii) enhancing the removal of diffusion barriers to dye molecules, (iii) developing additional accessible regions to dye (iv) decreasing the scattering coefficient of fabric surface (Mori et al., 1993 and Traore, 1997). Cellulases act by polishing the surface of the cotton fiber which reduced light scattering. Colours appear darker with less light scatter. 
When colour strength (K/S) of three swelling agents i.e. Sodium hydroxide, Ethylenediamine and Zinc Chloride (Table 1) treated samples were compared, it was found that maximum K/S was shown by Sodium hydroxide followed by Ethylenediamine and Zinc Chloride treated samples. The $\mathrm{K} / \mathrm{S}$ value of Sodium hydroxide treated samples, without mordant, mordanted with Babool bark bark, Myrobolan, Alum and Copper sulphate treated were found to be 2.995, 5.157, 5.438, 5.443 and 6.672, respectively. The K/S value of Ethylenediamine treated samples, without mordant, mordanted with Babool bark, Myrobolan, Alum and Copper sulphate treated were observed as 2.834, 4.923, 5.273, 5.314 and 6.218, respectively whereas the K/S value of Zinc Chloride treated samples, without mordant, mordanted with Babool bark bark, Myrobolan, Alum and Copper sulphate treated were observed as 2.812, 4.743, 5.142, 5.146 and 6.128, respectively. Maximum $\mathrm{K} / \mathrm{S}$ value in case of Sodium hydroxide followed by Ethylenediamine treated samples has been attributed to their ability to bring about intra and intercrystalline swelling which provides higher accessibility to dye molecules, whereas minimum K/S value of Zinc chloride treated samples is due to only intercrystalline swelling. As a result of intra and intercrystalline swelling maximum water absorption was observed in case of Sodium hydroxide followed by Ethylenediamine and Zinc chloride.

As shown in table 1 the swelling treatment followed by cellulase enzyme treatment and dyed with Butea frondosa dye showed higher depth in colour values (K/S). The maximum swelling caused by the Sodium hydroxide followed by cellulase enzyme treatment gave higher K/S value than Ethylenediamine and Zinc chloride treated samples followed by cellulase enzyme treatment. The $\mathrm{K} / \mathrm{S}$ of Sodium hydroxide treated samples followed by acid cellulase enzyme treatment, without mordant, mordanted with Babool bark, Myrobolan, Alum and Copper sulphate were 3.278, 5.557, 5.943, 6.835 and 7.944, respectively. The K/S of Ethylenediamine treated samples followed by acid cellulase enzyme treatment, without mordant, mordanted with Babool bark, Myrobolan, Alum and Copper sulphate were found to be 3.176, 5.513, 5.874, 6.610 and 7.934, respectively whereas the K/S of Zinc chloride treated samples followed by acid cellulase enzyme treatment, without mordant, mordanted with Babool bark, Myrobolan, Alum and Copper sulphate were observed as $3.148,5.424,5.845,6.465$ and 7.747, respectively. The K/S of Sodium hydroxide treated samples followed by neutral cellulase enzyme treatment, without mordant, mordanted with Babool bark, Myrobolan, Alum and Copper sulphate were found to be 3.481, 6.021 6.343, 7.248 and 8.324, respectively. The K/S of Ethylenediamine treated samples followed by neutral cellulase enzyme treatment, without mordant, mordanted with Babool bark, Myrobolan, Alum and Copper sulphate were observed as 3.372, 5.857, 6.127, 7.121 and 8.221, respectively.

The above findings could be attributed to the higher accessibility of dye molecules due to opening of structure by swelling agents and also due to enzyme attack on 1, 4, $\beta$-glycoside linkage on cellulose. The results could also be understood in the manner that the swelling agents lowers the crystallinity of the substrate and the cellulase catalytic reaction proceeds preferentially in the less crystalline regions of substrate. Swelling agents, primarily strong electrolytic solvents have been employed to pretreat cellulose. Two types of swelling agents are known one is intercrystalline and the other intracrystalline. For example, water can penetrate and loosen only the amorphous region of cellulose; this is considered as an intercrystalline swelling agent. On the other hand, swelling agents, such as certain salts and alkaline solutions, affect both the amorphous and crystalline regions of cellulose; they are called intracrystalline swelling agents. In other words, intracrystalline swelling agents are effective in loosening the crystalline region of cellulose. The action of swelling 
agents inherits the outer skin on cotton fibers and causes it to split and form collars; the inner cellulose layers swell rapidly the collars (Fan et al, 1987). Due to loosening of crystalline region of cellulose by swelling agents, the absorbency of the fabric towards water and dyes is increased.

\subsection{COLOURFASTNESS PROPERTIES}

\subsubsection{LIGHT FASTNESS OF SAMPLES TREATED WITH CELLULASE ENZYMES AND SWELLING AGENTS AND DYED WITH BUTEA FRONDOSA DYE AND MORDANTED WITH BABOOL BARK}

Table 2 reveals that in case of Butea frondosa dye the untreated mordanted sample showed between poor to fair (2-3) light fastness. Samples treated with Zinc chloride showed fair to fairly good (3-4) light fastness, whereas other treated samples with swelling agents and cellulase enzymes showed fairly good (4) light fastness. It was found that treatment had fairly improved the light fastness.

\subsubsection{WASH FASTNESS OF SAMPLES TREATED WITH CELLULASE ENZYMES AND SWELLING AGENTS AND DYED WITH BUTEA FRONDOSA DYE AND MORDANTED WITH BABOOL BARK}

It is clear from the table 2 that in case of Butea frondosa dye, the colour of untreated mordanted sample was noticeably (3) changed. The same sample gave noticeable (3) staining on wool and cotton. Samples treated with Ethylenediamine and Zinc chloride showed between noticeable to slight (3-4) change in colour, whereas other treated samples showed slight (4) change in colour. Staining on wool and cotton showed by Ethylenediamine and Zinc chloride ranged between noticeable to slight (3-4), whereas other treated samples showed slight (4) staining on wool and cotton. It was observed from the results that the pretreatment with cellulases and swelling agents had slightly improved the washing fastness of the handloom cotton.

\subsubsection{RUBBING FASTNESS OF SAMPLES TREATED WITH CELLULASE ENZYMES AND SWELLING AGENTS AND DYED WITH BUTEA FRONDOSA DYE AND MORDANTED WITH BABOOL BARK}

It is evident from the table 2 that the untreated mordanted sample of Butea frondosa dye showed noticeable (3) change in colour in both dry and wet rubbing fastness. Noticeable (3) staining on both wool and cotton was shown in dry and wet rubbing fastness.

In case of dry rubbing tests samples treated with Ethylenediamine and Zinc chloride showed between noticeable to slight (3-4) change in colour, while other treated samples showed slight (4) change in colour. Staining on wool and cotton was observed between noticeable to slight (3-4) in case of samples treated with Ethylenediamine and Zinc chloride, whereas other treated samples showed slight (4) staining on wool and cotton. In case of wet rubbing tests, it was observed that all the treated samples with cellulase enzymes and swelling agents showed improvement and exhibited slight (4) change in colour and slight (4) staining on wool and cotton was observed. 


\subsubsection{PERSPIRATION FASTNESS OF SAMPLES TREATED WITH CELLULASE ENZYMES AND SWELLING AGENTS AND DYED WITH BUTEA FRONDOSA DYE AND MORDANTED WITH BABOOL BARK}

Table 2 showed that the change in colour and staining on wool and cotton for untreated mordanted sample was noticeable (3) in both acidic and alkaline perspiration. In acidic perspiration, the samples treated with Zinc chloride and Zinc chloride plus acid cellulase showed between noticeable to slight (3-4) change in colour as well as staining on wool and cotton were also between noticeable to slight (3-4). The other treated samples showed slight (4) change in colour and slight (4) staining on wool and cotton.

In case of alkaline perspiration, the samples treated with Zinc chloride and Zinc chloride plus acid cellulase showed between noticeable to slight (3-4) change in colour, while other treated samples exhibited slight (4) change in colour. Staining on wool and cotton was between noticeable to slight (3-4) in case of samples treated with Zinc chloride, whereas other treated samples showed slight (4) staining on wool and cotton.

In case of handloom cotton dyed with Butea frondosa dye and mordanted with Babool bark, the first rank was secured by the samples treated with Acid cellulase, Neutral cellulase, Sodium hydroxide and Sodium hydroxide and Ethylenediamine in combination with Acid cellulase and also Sodium hydroxide, Ethylenediamine and Zinc chloride when combined with Neutral cellulase. The second rank was occupied by sample treated with Zinc chloride plus Acid cellulase. Ethylenediamine and Zinc chloride obtained third and fourth rank, respectively. Untreated mordanted sample secured last fifth rank.

\section{CONCLUSION}

It was found that for all the enzyme treated (acid and neutral cellulase) as well as swelling agents treated (Sodium hydroxide, Ethylenediamine and Zinc chloride) samples, the K/S values, and thus the colour strength were increased in comparison to the untreated samples.Among the three swelling agents, Sodium hydroxide treated sample obtained the highest colour strength (K/S) followed by Ethylenediamine and Zinc chloride treated samples. The K/S values of cellulase treated samples were enhanced in comparison with untreated samples. However, higher depth of dyeing was exhibited by neutral cellulase enzyme than acid cellulase enzyme treated samples.

The swelling agent treatment followed by cellulase enzyme treatment showed higher depth in colour values $(\mathrm{K} / \mathrm{S}$. The maximum swelling caused by the Sodium hydroxide followed by cellulase enzyme treatment gave higher K/S value than Ethylenediamine and Zinc chloride treated samples followed by cellulase treatment. The swelling agents treated samples followed by neutral cellulase enzyme treatment showed higher depth of dyeing than acid cellulase enzyme treatment.

\section{REFERENCES}

[1] Buschle-Diller, G., Walsh, W.K. \& Radhakrishnaiah, P. 1998. Natl. Center Ann. Rep. Available at http://www.ntcresearch.org/pdf-rpts/Bref0998/chem-mod.pdf.Pp1-7. 
[2] Constanta, I., Christian, S.\& Thomas, B. 2006. 'Alkaline treatment of cotton in different reagent mixtures with reduced water content. I. Influence of alkali type and additives.', Journal of Applied Polymer Sci., vol. 99, no. 5, pp. 2848-2855.

[3] Fan, L.T., Gharpurag, M.M. \& Lee, Y.H. 1987, Biotechnology monograph, vol. 3, Cellulose hydrolysis, New York, Springer Verlag, Berlin, pp. 14-17, 66.

[4] Furter, R., Ghorashi, H. \& Schleth, A. 2007, 'The role of cotton classification in the textile industry', Asian Textile Journal, vol. 16, no. 5, pp. 67.

[5] Lewin, M. 2007, Handbook of Fiber Chemistry, $3^{\text {rd }}$ Edition, CRC Press Taylor \& Francis Group, pp. 99-103.

[6] Mehta, P.V. \& Bhardwaj, S.K. 1998, Managing quality in the apparel industry, New Age International Publishers, New Delhi, 327p.

[7] Mori, R., Haga, T. \& Tekagishi, T. 1993, Journal of Applied Polymer Science, vol. 48, pp. 1223.

[8] Nair, G.P. 2006, 'Studies on mercerizing and other swelling treatments of cotton-I. Heterogeneous acid hydrolysis of cotton and cotton treated with swelling agents. Part II: Studies based on changes in DP during acid hydrolysis- Materials, treatments and method of analysis', Colourage, vol. 53, no. 6, pp. 69-72.

[9] Tarore, M.K., AATCC Book of Papers. 1997. International Conference, $28^{\text {th }}$ September$1^{\text {st }}$ October, Atlanta, Ga. USA. 64.

[10] Thakare, A.M. 2006, 'Improvement in dyeability of cotton with hydroxylamine', Asian Textile Journal, vol. 15, no. 11, pp. 78-81.

[11] Tsatsaroni, E., Kyriakides, M.L. \& Eleftheriadis, 1998, 'Comparative study of dyeing properties of two yellow natural pigments. Effect of enzyme and proteins', Dyes and Pigments, vol. 37, no. 4, pp. 307-315.

Table 1: Colour strength (K/S) of cellulases and swelling agents treated samples dyed with Butea frondosa dye

\begin{tabular}{|c|c|c|c|c|c|}
\hline Samples & $\begin{array}{r}\text { Without mordant } \\
(\mathrm{K} / \mathrm{S})\end{array}$ & $\begin{array}{r}\text { Babool bark } \\
\qquad(\mathrm{K} / \mathrm{S})\end{array}$ & Harda $(\mathrm{K} / \mathrm{S})$ & Alum (K/S) & $\begin{array}{r}\text { Tartaric acid } \\
(\mathrm{K} / \mathrm{S})\end{array}$ \\
\hline Untreated & 2.709 & 3.986 & 4.124 & 4.268 & 4.823 \\
\hline Acid cellulase & $2.948(8.10)$ & $4.994(20.18)$ & $5.326(22.56)$ & $5.549(23.08)$ & $6.648(27.45)$ \\
\hline Neutral cellulase & $3.137(13.64)$ & $5.418(26.43)$ & $5.530(25.42)$ & $5.991(28.75)$ & $6.875(29.84)$ \\
\hline Sodium hydroxide & $2.995(9.54)$ & $5.157(22.70)$ & $5.438(24.16)$ & $5.443(27.53)$ & $6.712(28.14)$ \\
\hline Ethylenediamine & $2.834(4.41)$ & $4.923(19.03)$ & $5.273(21.79)$ & $5.314(19.68)$ & $6.218(22.43)$ \\
\hline Zinc chloride & $2.812(3.66)$ & $4.743(15.96)$ & $5.142(19.79)$ & $5.146(17.06)$ & $6.128(21.29)$ \\
\hline $\begin{array}{c}\text { Sodium hydroxide } \\
+\quad \text { Acid } \\
\text { cellulase }\end{array}$ & $\begin{array}{r}3.278(17.35) \\
(10.06 a)\end{array}$ & $\begin{array}{r}5.557(27.27) \\
(10.13 a)\end{array}$ & $\begin{array}{r}5.943(30.60) \\
(10.38 a)\end{array}$ & $\begin{array}{r}6.835(37.55) \\
(18.81 \mathrm{a})\end{array}$ & $\begin{array}{r}7.944(39.28) \\
(16.31 \mathrm{a})\end{array}$ \\
\hline $\begin{array}{c}\text { Ethylenediamine }+ \\
\text { Acid } \\
\text { cellulase }\end{array}$ & $\begin{array}{r}3.176(14.70) \\
(7.17 a)\end{array}$ & $\begin{array}{r}5.513(27.69) \\
(9.41 \mathrm{a})\end{array}$ & $\begin{array}{r}5.874(29.79) \\
(9.32 a)\end{array}$ & $\begin{array}{r}6.610(35.43) \\
(16.05 a)\end{array}$ & $\begin{array}{r}7.934(38.43) \\
(15.13 a)\end{array}$ \\
\hline
\end{tabular}




\begin{tabular}{|r|r|r|r|r|r|}
\hline Zinc chloride & $3.148(13.94)$ & $5.424(26.51)$ & $5.845(29.44)$ & $6.465(33.98)$ & $7.747(37.74)$ \\
Acid & $(6.35 \mathrm{a})$ & $(7.92 \mathrm{a})$ & $(8.87 \mathrm{a})$ & $(14.16 \mathrm{a})$ & $(14.18 \mathrm{a})$ \\
cellulase & & & & & \\
\hline $\begin{array}{r}\text { Sodium hydroxide } \\
+ \text { Neutral } \\
\text { cellulase }\end{array}$ & $3.481(22.26)$ & $6.021(33.79)$ & $6.343(34.98)$ & $7.248(41.11)$ & $8.324(42.05)$ \\
& $(9.88 \mathrm{~b})$ & $(10.01 \mathrm{~b})$ & $(12.81 \mathrm{~b})$ & $(17.34 \mathrm{~b})$ & $(17.40 \mathrm{~b})$ \\
\hline $\begin{array}{c}\text { Ethylenediamine }+ \\
\text { Neutral } \\
\text { cellulase }\end{array}$ & $3.372(19.66)$ & $5.857(31.94)$ & $6.127(32.69)$ & $7.121(40.06)$ & $8.221(41.33)$ \\
Zinc $\begin{array}{c}\text { chloride }+ \\
\text { Neutral } \\
\text { cellulase }\end{array}$ & $(6.96 \mathrm{~b})$ & $(7.49 \mathrm{~b})$ & $(9.74 \mathrm{~b})$ & $(15.86 \mathrm{~b})$ & $(16.37 \mathrm{~b})$ \\
& $(5.25 \mathrm{~b})$ & & & & \\
\hline
\end{tabular}

1. Figures in parenthesis indicate percentage increase in colour strength of treated samples in comparison with untreated samples.

2. Figures in parenthesis with subscript letter $a$ and $b$ indicate percentage increase in colour strength of treated samples in comparison of acid and neutral cellulase treatment, respectively.

Table 2: Effect of enzymatic and swelling agents treatment on colourfastness properties of handloom cotton dyed with Butea frondosa dye and mordanted with Babool bark

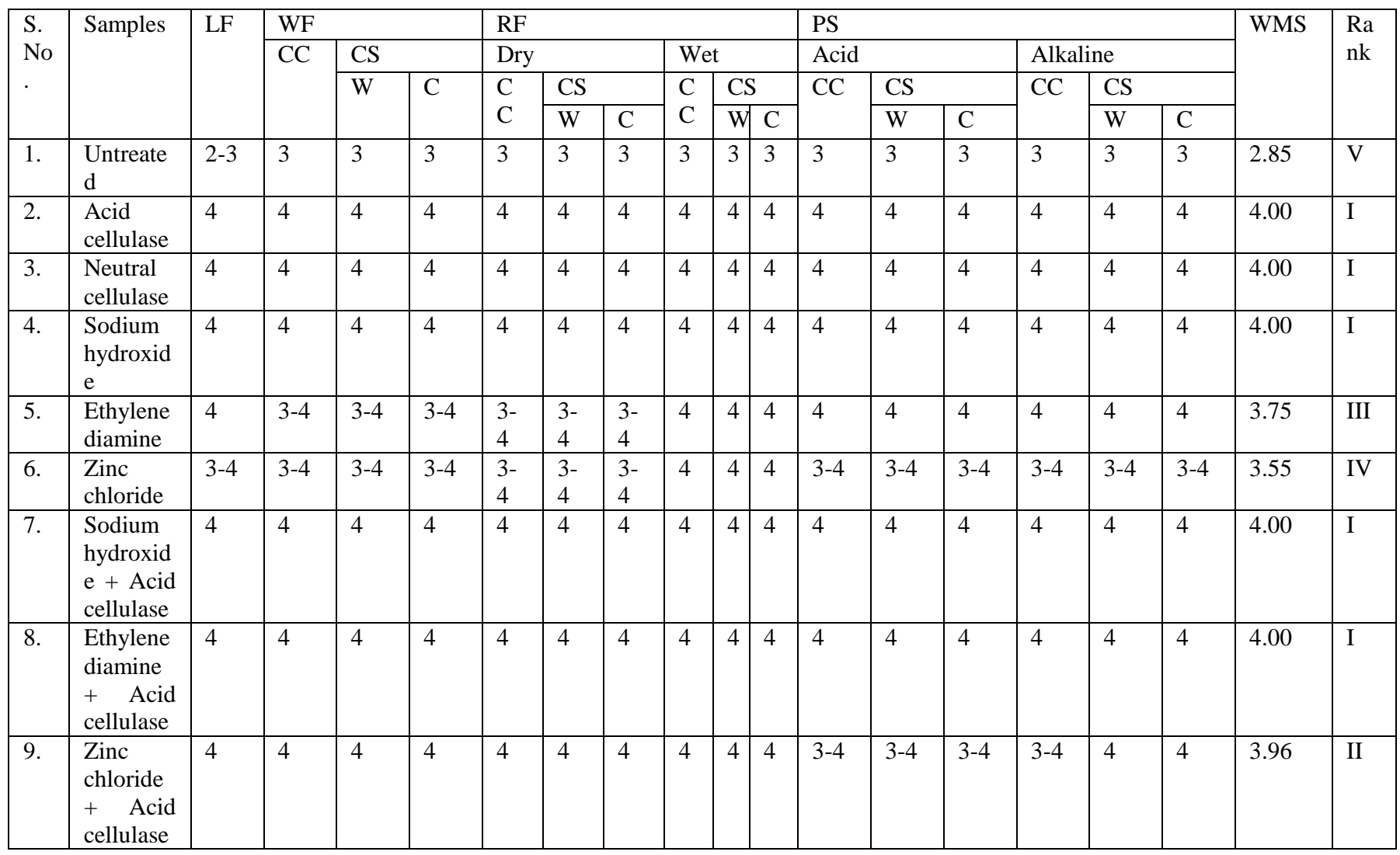




\begin{tabular}{|l|l|l|l|l|l|l|l|l|l|l|l|l|l|l|l|l|l|l|l|}
\hline 10. & $\begin{array}{l}\text { Sodium } \\
\text { hydroxid } \\
\text { e + } \\
\text { Neutral } \\
\text { cellulase }\end{array}$ & 4 & 4 & 4 & 4 & 4 & 4 & 4 & 4 & 4 & 4 & 4 & 4 & 4 & 4 & 4 & 4 & 4.00 & I \\
\hline 11. & $\begin{array}{l}\text { Ethylene } \\
\text { diamine } \\
+ \text { Neutral } \\
\text { cellulase }\end{array}$ & 4 & 4 & 4 & 4 & 4 & 4 & 4 & 4 & 4 & 4 & 4 & 4 & 4 & 4 & 4 & 4 & 4.00 & I \\
\hline 12. & $\begin{array}{l}\text { Zinc } \\
\text { chloride } \\
\text { Neutral } \\
\text { cellulase }\end{array}$
\end{tabular}

$\mathrm{LF}=$ Light fastness, $\mathrm{WF}=$ Washing fastness, $\mathrm{RF}=$ Rubbing fastness, $\mathrm{PF}=$ Perspiration fastness, $\mathrm{CC}=$ Change in colour, $\mathrm{CS}=$ Colour staining, $\mathrm{W}=\mathrm{Wool}, \mathrm{C}=$ Cotton, $\mathrm{WMS}=$ Weighted mean score 